University of Nebraska - Lincoln

DigitalCommons@University of Nebraska - Lincoln

1981

\title{
Thoracic Crop Formation Following Dealation by Virgin Females of Two Species of Solenopsis
}

\author{
B. M. Glancey \\ USDA
}

A. Glover

USDA

C. S. Lofgren

USDA

Follow this and additional works at: https://digitalcommons.unl.edu/entomologyother

Part of the Entomology Commons

Glancey, B. M.; Glover, A.; and Lofgren, C. S., "Thoracic Crop Formation Following Dealation by Virgin Females of Two Species of Solenopsis" (1981). Entomology Papers from Other Sources. 29.

https://digitalcommons.unl.edu/entomologyother/29

This Article is brought to you for free and open access by the Entomology Collections, Miscellaneous at DigitalCommons@University of Nebraska - Lincoln. It has been accepted for inclusion in Entomology Papers from Other Sources by an authorized administrator of DigitalCommons@University of Nebraska - Lincoln. 


\section{SCIENTIFIC NOTES}

THORACIC CROP FORMATION FOLLOWING DEALATION BY VIRGIN FEMALES OF TWO SPECIES OF SOLENOPSIS-(Note). The enlargement of the esophagus following dealation to form a "thoracic" crop has been reported for Lasius queens by Janet (1907. Ducourtieux and Gout 149 p.), for queen ants of 5 genera by Petersen-Braun and Buschinger (1975. Insectes Sociaux 22: 51-66) and for mated and unmated queens of the red imported fire ant, Solenopsis invicta Buren by Glancey et al. (1981. Sociobiology $6: 119-27)$. It is generally concluded that the thoracic crop provides space for contents of the gastral crop as ovarian development progresses. The contents of the thoracic crop in S. invicta are composed of triglycerides, free fatty acids and hydrocarbons, and these have been shown (R. K. Vander Meer, unpublished data, 1980) to be identical to the fluid in the gastral crop. These materials serve as food for the immature stages and the queen during the founding of a new colony. Virgin females that lose their wings before mating also develop a thoracic crop, but the process takes longer than in mated queens.

We have observed similar physiological changes in 2 other species of fire ants, S. richteri Forel, the black imported fire ant, and S. geminata (F.), the "tropical" fire ant. Two-week-old virgin females were confined singly in 1-dram vials on moistened cotton swabs and held in the laboratory at $27^{\circ} \mathrm{C}$. The females dealated under these confined conditions, and $3 \mathrm{~S}$. geminata and $10 \mathrm{~S}$. richteri females were sacrificed at $0,3,6,9$, and 12 days postdealation. Observations were made on the esophagus following flight muscle histolysis. In addition, we observed the gastral crop, ovaries, fat body, and postpharyngeal gland.

Changes noted with both species paralleled those reported for S. invicta (Glancey ibid.) ; S. richteri histolyzed the flight muscles and developed the thoracic crop in 9 days as compared to 15 days for $S$. geminata. In addition, $S$. richteri showed complete ovariole development in 6 days whereas $S$. geminata required 15 days. The postpharyngeal glands of both species remained filled during the entire time of the experiment. Of particular interest was the observation that in $S$. richteri, very little change was seen in the fat body, whereas $S$. geminata appeared to deplete almost all of their reserves.

Since virgin females were isolated from workers and no food was provided, the conclusion must be reached that the fluid in the thoracic crop came from an internal source, namely the gastral crop. The role of dealated virgin females in colonies is as yet unknown, but because of the high food value of the material found in crops of both species, they could serve as a food source during times of nutritional stress.-B. M. GLANCEY, A. GLover, AND C. S. LoFGReN; Insects Affecting Man and Animals Research Laboratory, ARS, USDA; Gainesville, FL 32604 USA. 